\title{
Effects of Gamma Irradiation on Phenotypic Changes in Vanda Hybrid
}

\author{
Sri Hartati ${ }^{12^{*}}$, Prasetyo ${ }^{1}$, and Endang Setia Muliawati ${ }^{1}$ \\ ${ }^{1}$ Department of Agrotechnology, Faculty of Agriculture, Universitas Sebelas Maret, Jl. Ir. Sutami 36A \\ Kentingan Jebres Surakarta 57126, Indonesia \\ ${ }^{2}$ Center for Biotechnology and Biodiversity Research and Development, Institute of Research and Community \\ Services, Universitas Sebelas Maret, J1. Ir. Sutami 36A Kentingan Jebres Surakarta 57126, Indonesia \\ *Corresponding Author: tatik_oc@yahoo.com
}

\begin{abstract}
Vanda Orchid is one of the most popular ornamental plants. Orchids have slow growth. One way to overcome this weakness is by using gamma-ray irradiation. This research aimed to study the morphological characters of various radiation doses resulting from the crossing of the Vanda Orchid. This study was carried out by observing the characters of vegetative growth for each plant on $0 \mathrm{~Gy}, 10$ Gy, $20 \mathrm{~Gy}, 30 \mathrm{~Gy}, 40 \mathrm{~Gy}$, and $50 \mathrm{~Gy}$ doses of gamma irradiation treatments. The observed variables were the increase in plant height, leaf length, root length, number of roots, number of leaves, leaf width, and leaf color. The results showed that the dose of gamma-ray irradiation were able to increase plant height. $10 \mathrm{~Gy}$ and $20 \mathrm{~Gy}$, gamma-ray irradiation doses, resulted in discolored yellowing of orchid leaves. The discoloration of orchid leaves to light green occurs at irradiation doses of $30 \mathrm{~Gy}, 40 \mathrm{~Gy}$, and $50 \mathrm{~Gy}$. The morphological characteristics of Vanda sp. hybrid results gamma irradiation are high at dose 10-40 Gy.
\end{abstract}

Keywords: characteristics; morphological; orchid

Cite this as: Hartati, S., Prasetyo, and Muliawati, E. S. (2021). Effects of Gamma Irradiation on Phenotypic Changes in Vanda Hybrid. Journal of Biodiversity and Biotechnology. 1(1), 1-4. doi: http://dx.doi.org/10.20961/jbb.v1i1.49298.

\section{Introduction}

Orchid is one of the prevalent ornamental plants. Hadi et al. (1) stated that orchids have great diversity in both the tropics and subtropics. Indonesia has a vast potential for orchids. There are around 5000 types of orchids and more than 200 of them can be commercialized. One of the most popular types of orchids in Indonesia is Vanda Orchid. Vanda Orchid has a unique and attractive shape. Hartati and Darsana (2) stated that the morphological characterization of orchids is necessary to preserve germplasm and select a variety of natural orchid germplasm with superior properties.

The process of making new orchid varieties is conventionally carried out by crossing techniques which are carried out with human assistance. Developed countries have done the process of making new varieties with better technology. One technology for making varieties is done with the help of irradiation rays. Irradiation can make plants into mutants, so the expected varieties could be obtained. Irradiation is a faster method that can produce mutant plants that have certain advantages.

Efforts to obtain superior varieties are often made by crossing various existing varieties. This method is considered inefficient because it requires quite longer time. One of the technologies for making varieties is done with the help of irradiation rays. Haris et al. (3) states that, induction of plants with gamma rays can improve the quality and quantity of plants because they can change the nature of plants. Irradiation is an effective source for producing genetic diversity in plants (4). Mahendra et al. (5) states, gamma-ray irradiation has the benefit of combining the advantages of organic and inorganic materials. This study aimed to determine the differences in morphological 
characteristics between the crossing Vanda sp. irradiation results.

\section{Materials and Methods}

The research was carried out in two places. The radiation was carried out at BATAN Jakarta, then the F1 hybrid from Vanda celebica and Vanda dearei were acclimatized in the greenhouse at the village of Plosorejo Matesih, Karanganyar, from July 2018 to January 2019.

The study was conducted by observing each individual in the control ( $0 \mathrm{~Gy}), 10 \mathrm{~Gy}, 20$ Gy, 30 Gy, 40 Gy, and 50 Gy treatment plants. The data obtained during the observations were analyzed in the descriptive method by comparing each plant in the various doses of radiation treatment with the control treatment. Observation variables consisted of plant height, plant length, root length, number of roots, number of leaves, leaf width, and leaf color.

\section{Results and Discussion}

Plant height

The growth measurements of mutant orchid plants are showed in table 1. Mutant plants did not show any changes in height compared with control plants. Gamma-ray irradiation is thought to cause stunted root growth due to stress. Physiological changes can be an imbalance of the hormone auxin in plants (6). Auxin is a hormone that regulates various developmental processes such as stem extension, apical dominance, and root initiation (7). High-dose irradiation interferes with protein synthesis, hormone balance, leaf gas exchange, water exchange, and enzyme activity. High irradiation doses changed the ratio of auxin and cytokinin to phytohormones, thereby changing cell differentiation patterns (8).

The increase in plant height occurs in 10 and $30 \mathrm{~Gy}$ irradiation, with $9.84 \mathrm{~cm}$ and $9.25 \mathrm{~cm}$ respectively, then decreases were at 20,40, and 50 Gy. Physiological damage caused by gamma irradiation can include cell death, inhibition of cell division, increased frequency of tissue formation, and changes in reproductive capacity. Increasing the dose of gamma-ray radiation can cause a decrease in plant height due to gamma rays that damage the plant chromosome structure, thus affecting plant growth (9).

Table 1. The average of plant height, leaf length, root length, number of roots, number of leaves, leaf width in various doses of gamma irradiation

\begin{tabular}{ccccccc}
\hline Dose & $\begin{array}{c}\text { Plant height } \\
(\mathrm{cm})\end{array}$ & $\begin{array}{c}\text { Leaf length } \\
(\mathrm{cm})\end{array}$ & $\begin{array}{c}\text { Root length } \\
(\mathrm{cm})\end{array}$ & $\begin{array}{c}\text { Number of } \\
\text { roots }\end{array}$ & $\begin{array}{c}\text { Number of } \\
\text { leaves }\end{array}$ & $\begin{array}{c}\text { Leaf width } \\
(\mathrm{cm})\end{array}$ \\
\hline $0 \mathrm{~Gy}$ & 8.80 & 35.90 & 38.05 & 7.75 & 12.00 & 1.98 \\
$10 \mathrm{~Gy}$ & 9.84 & 33.76 & 32.60 & 6.60 & 13.60 & 2.14 \\
$20 \mathrm{~Gy}$ & 8.88 & 31.00 & 35.18 & 6.00 & 12.83 & 2.11 \\
$30 \mathrm{~Gy}$ & 9.25 & 34.97 & 39.22 & 6.75 & 14.00 & 2.03 \\
$40 \mathrm{~Gy}$ & 8.37 & 31.50 & 23.63 & 5.33 & 14.33 & 1.97 \\
$50 \mathrm{~Gy}$ & 8.00 & 31.30 & 25.64 & 5.80 & 13.40 & 1.86 \\
\hline
\end{tabular}

\section{Leaf length and width}

Leaves are important parts of a plant. Leaf length can affect photosynthesis in plants. Gamma-ray irradiation at certain doses causes changes in plant phenotypes. Gamma rays can generate free radicals in cells, which can destroy essential components of plant cells and affect plant morphology, anatomy, biochemistry, and physiology differently depending on the level of irradiation (10). The most prominent and easily detectable parts of the plant after irradiation are the leaves (11). The leaf length of mutant plants is shorter than control plants. Table 1 showed that the average leaf length of the control plant about $35.90 \mathrm{~cm}$. Mutant plants with the highest average leaf length was found in 30 Gy with
$34.97 \mathrm{~cm}$, and the shortest average leaf length was found in 20 Gy treatment with $31 \mathrm{~cm}$.

The increasing width of the orchid leaves will affect the photosynthesis process and absorption of essential plant elements. The wider the leaf of the orchid, the easier it is for the plant to absorb water and nutrients. Based on Table 1, the leaf width of the mutant orchids is significantly differed than that of nonirradiated. The widest leaves of mutant orchids were in $10 \mathrm{~Gy}$ dose with an average of $2.14 \mathrm{~cm}$. The optimal dose for leaf width was known at a dose of $10 \mathrm{~Gy}$, and the size of the leaf width decreased along with the increase of irradiation dose. Each irradiated individual plant with gamma rays has a different sensitivity to 
irradiation dose. Generally, the higher the irradiation dose caused stunted leaf growth.

\section{Root length}

The root is the place where plants grow. The increase in root length is expected to make plants stronger. Irradiation on orchids is expected to increase the length of orchid plants. Based on table 1, it is known that control plants had the highest root length compared to all irradiated plants. The root length of mutant plants incread along with the increase of irradiation doses until its peak at the dose of 30 Gy, then decreasing at dose 40 Gy. Gamma-ray irradiation at low doses can increase growth, whereas high doses showed slow growth (12). Gamma-ray irradiation can cause random mutations that can cause physiological damage in the metabolism of cell development so that its growth potential can be faster or slower (13). Mutant plants with the highest root length were found in the dose $30 \mathrm{~Gy}$, and the lowest root length was found in $40 \mathrm{~Gy}$.

\section{Number of roots and leaves}

Gamma-ray irradiation inhibits the number of roots. All mutant plants have fewer roots than non-irradiated plants. The same thing was found in Lestari et al. (14) study, that increasing the dose of irradiation caused the number of roots of Dendrobium sylvanum and Phalaenopsis sp. to decrease. The average number of roots of non-irradiated plants was 7.75. The highest number of roots was in irradiated plants with a dose of $30 \mathrm{~Gy}$, while the lowest was in a dose of $40 \mathrm{~Gy}$. The low number of roots due to the dose of gamma-ray irradiation causes chromosomal changes to affect the growth of the radicles.

Leaves are essential parts of plants in photosynthesis. The increasing number of leaves will affect the absorption of water and nutrients needed for plants. In contrast with the number of roots, mutant plants at all doses had more leaves than control. The number of leaves increased with the increase in irradiation dose, and the peak was at 40 Gy. Based on Table 1, the highest number of leaves were found in the dose 30 Gy and 40 Gy, 14 and 14.33, respectively. Changes in cells in plant organs caused by gamma-ray irradiation can interfere with plant physiological processes (15).

\section{Leaf color}

Gamma irradiation can cause cell change in certain organ plants. Leaf color changes can be identified using the Munsell Color Chart. The results of observations of changes in leaf color are shown in Table 2. Non-irradiated plants had light green leaves color. The same result was shown in mutant plants at $20 \mathrm{~Gy}, 30$ Gy, $40 \mathrm{~Gy}$, and $50 \mathrm{~Gy}$. While mutant plants dose, 10 Gy showed yellowing on leaves. The 20-50 Gy dose gamma irradiation in this study did not cause discoloration of the orchid leaves, in contrast to Astutik (15) which showed that the color of the leaves darkened with increasing irradiation doses. Color changes occur in mutant orchid by irradiation of $10 \mathrm{~Gy}$, which showed a yellowish color. Leaf discoloration of orchid plantlets occured due to damage in chlorophyll after irradiation (14).

Table 2. Color change of vanda leaf with various dose treatment of gamma irradiation

\begin{tabular}{ll}
\hline Dose & Leaf Color \\
\hline $0 \mathrm{~Gy}$ & $7.5 \mathrm{~Gy} 6 / 6.5$ \\
$10 \mathrm{~Gy}$ & $2.5 \mathrm{~Gy} 6 / 6.5$ \\
$20 \mathrm{~Gy}$ & $7.5 \mathrm{~Gy} 6 / 6.5$ \\
$30 \mathrm{~Gy}$ & $7.5 \mathrm{~Gy} 6 / 6.5$ \\
$40 \mathrm{~Gy}$ & $7.5 \mathrm{~Gy} 6 / 6.5$ \\
$50 \mathrm{~Gy}$ & $7.5 \mathrm{~Gy} 6 / 6.5$ \\
\hline
\end{tabular}

\section{Conclusion}

The increased gamma-ray irradiation dose in Vanda sp. hybrid can increase the diversity of plant height, leaf length, root length, and the number of roots. A 10 Gy gamma-ray irradiation dose increased plant height and changed the color of the yellowing orchid leaves. Irradiation doses of $20 \mathrm{~Gy}, 30 \mathrm{~Gy}, 40$ Gy, and 50 Gy resulted in the color of orchid leaves became light green.

\section{Conflict of Interest}

All authors declare no conflicts of interest in this section.

\section{References}

1. Hadi H, Razali SNS, Awadh AI. A comprehensive review of the cosmeceutical benefits of vanda species (Orchidaceae). Nat Prod Commun. 2015;10(8):1483-8.

2. Hartati S, Darsana L. Morphological characterization of natural orchids in the context of germplasm conservation. $\mathrm{J}$ Agron Indones. 2015;43(2):133.

3. Haris A, Abdullah, Bakhtiar, Subaedah, Aminah, Jusoff K. Gamma ray radiation mutant rice on local aged dwarf. Middle 
East J Sci Res.2013;15(8):1160-4.

4. El-Degwy IS. Mutation Induced Genetic Variability in Rice (Oryza sativa L.). Int J Agric Crop Sci. 2013;5(23):2789-94.

5. Mahendra K, Nayak KK, Fernandes BJ, Udayashankar NK. Gamma irradiation effect on structural, optical and electrical properties of organometallic potassium hydrogen oxalate oxalic acid dihydrate single crystal. J Mater Sci Mater Electron. 2018;29(22):18905-12.

6. Rosmala A, Khumaida N, Sukma D. Morphological changes and growth of The Handeuleum (Graptophyllum pictum L. Griff) due to gamma ray irradiation. J Agron Indones. 2016;43(3):241.

7. Pimonrat P, Suraninpong P, Wuthisuthimethavee S. Acute effect of gamma radiation on stable characteristics of Spathoglottis plicata Blume. Acta Hortic. 2012;953:173-80.

8. Setiawan RB, Khumaida N, Dinarti D. Induction of wheat embryogenic callus mutation (Triticum aestivum L.) through gamma ray irradiation for high temperature tolerance. J Agron Indones. 2015;43(1):36.

9. Dewi SDN., Agustina PLP., Nuriadi I. Effect of gamma ray radiation on green bean plants (Vigna radiata $\mathrm{L}$.) on saline conditions. Agroekoteknologi. 2013;1(2):94538.

10. Dehgahi R, Joniyas A. Review of research on dendrobium sonia-28, a hybrid from orchidacea family and mutation as somaclonal variation. Int $\mathbf{J}$ Biosci. 2017;10(06):29-47.

11. Srivastava D, Gayatri MC, Sarangi SK. In vitro mutagenesis and characterization of mutants through morphological and genetic analysis in orchid Aerides crispa Lindl. Indian $\mathbf{J}$ Exp Biol. 2018;56:385-94.

12. Kapare V, Satdive R, Fulzele DP, Malpathak N. Impact of gamma irradiation induced variation in cell growth and phytoecdysteroid production in Sesuvium portulacastrum. J Plant Growth Regul. 2017;36(4):919-30.

13. Rosyidah AY, Iis AS, Darusman LK. Induction of physical mutations by gamma ray irradiation in turmeric (Curcuma domestica Val.). J Hortik Indones. 2015;5(2):84.

14. Lestari EP, Yunus A, Sugiyarto. The morphology effect of Dendrobium sylvanum and Phalaenopsis sp. with gamma ray irradiation. In: Proceedings of the National Seminar of the Faculty of Agriculture, UNS. Surakarta: Faculty of Agriculture Universitas Sebelas Maret; 2018. p. 143-52.

15. Astutik. Diversity of phalaenopsis clons from gamma radiation: changes in phenotypes of vegetative growth phase. Buana Sains. 2012;12(1):37-42. 